\title{
Theoretical analysis and relationship of government and private investment on economic growth and employment absorption
}

\author{
M. Ramadhan* \\ Sekolah Tinggi Ilmu Ekonomi Pancasetia (STIEPAN) Banjarmasin Indonesia.
}

Global Journal of Engineering and Technology Advances, 2021, 09(03), 059-067

Publication history: Received on 16 November 2021; revised on 19 December 2021; accepted on 21 December 2021

Article DOI: https://doi.org/10.30574/gjeta.2021.9.3.0167

\begin{abstract}
One of the goals to be achieved in developing public and private investment is to encourage economic growth and employment. Positive economic growth is needed because it means that it has driven faster economic growth and increased the absorption of Employment. This study aims to obtain an analysis of the theoretical relationship between government investment and private investment on economic growth and employment, especially in South Kalimantan Province as the object of research. South Kalimantan Province is one of the regions in Indonesia which has a large potential for natural resources. The method used in this research is to use Path Analysis and analysis of theoretical findings based on in-depth analysis of various literature studies and observations which are expected to prove that government investment and private investment affect employment and economic growth which in turn can affect poverty levels. . The results of the study are expected to obtain important theoretical findings that can contribute to the formulation of government policies.
\end{abstract}

Keywords: Study of theoretical relationship; Government and private investment; Economic growth; Employment absorption

\section{Introduction}

Economic development pursued by developing countries aims, among other things, to achieve prosperity and wellbeing for all of their people. To achieve the welfare of the people, the main problem faced by every developing country, including Indonesia, is the inequality of income distribution and poverty. Another major economic problem that occurs is high unemployment and continues to increase, which is currently a strong reason for the need for government intervention and policies to deal with this. The root of the unemployment problem can be solved by investing in both government investment and private investment which is expected to be able to absorb a large number of workers because of the positive relationship between investment, job opportunities, and economic growth which drives consumption to normal.

One of the tools of economic policy to improve people's welfare is the easy money policy, which is expected to create convenience in obtaining bank credit for investment. An increase in investment will increase the demand for investment goods and consumer goods so that it can increase the tendency of rising general prices (inflation). To suppress inflation, a tight money policy was implemented, which was marked by an increase in bank interest rates which was quite high and resulted in weak economic growth and a weak rate of job creation. The accumulation of capital depends on the ability to save and the willingness to save. Capital can be increased by increasing production and reducing consumption. This opinion is a mechanism for the formation of private capital which is a source of private investment, while the source of capital accumulation in the hands of the government as a source of government investment comes from taxes. The

\footnotetext{
* Corresponding author: M. Ramadhan

Sekolah Tinggi Ilmu Ekonomi Pancasetia (STIEPAN) Banjarmasin Indonesia.

Copyright (C) 2021 Author(s) retain the copyright of this article. This article is published under the terms of the Creative Commons Attribution Liscense 4.0.
} 
imposition of taxes for capitalists, landowners, and Employment is a government effort in financing development through government investment.

The increase that occurs in investment, both government investment and private investment will have an impact on economic growth, employment, and decreasing poverty levels, so this study will examine, prove and analyze all of them. This is following the theory of economic development which explains that an increase in national income and population development will expand the market and create savings that are used for investment needs.

One of the goals to be achieved in developing investment, especially with this private facility, is to encourage the level of economic growth. Positive economic growth is needed because it means it has moved the wheels of the economy faster. This movement brings an increase in production or added value and productivity in various economic chains and ultimately increases people's income and welfare. Therefore, it is quite important to measure the role of investment activities in increasing economic growth, employment, and their effect on poverty levels.

This study aims to obtain an analysis of the theoretical relationship between government investment and private investment on economic growth and employment, especially in South Kalimantan Province as the object of research. South Kalimantan Province is one of the regions in Indonesia that has a fairly large natural resource potential including the agricultural sector, plantation, and marine fisheries sub-sectors, as well as the coal mining sector which attracts investment activities both from domestic sources in the form of Domestic Investment (PMDN) and Foreign Investment (PMA). The survey of the Monitoring Committee for the Implementation of Regional Autonomy (KPPOD) in 2002 showed that institutions are the main factor determining the attractiveness of investment in an area, followed by sociopolitical conditions, physical infrastructure, regional economic conditions, and Employment productivity.

Previous research on the effect of government investment and private investment on economic growth, employment, and poverty levels has been partially carried out. Research on the effect of government investment and government investment on economic growth states that investment is one of the main component factors of economic growth. Aan Zulyanto et al (2019) in a previous study also concluded that local government investment and private investment will both encourage economic growth. This is different from the research results of Astika et al (2021) which show that private investment has a small impact on economic growth due to the very small value of profit sharing and royalties. This shows the inconsistency of the results of previous studies, particularly regarding the effect of private investment on economic growth.

Based on the background described, the formulation of the research problem is as follows:

- How are the theoretical analysis and the relationship between government investment and economic growth in districts/cities in South Kalimantan Province?

- How are the theoretical analysis and the relationship between private investment and the economic growth of districts/cities in South Kalimantan Province?

- How are the theoretical analysis and the relationship between government investment and employment in Regency/City in South Kalimantan Province?

- How do theoretical analysis and the relationship between private investment affect the absorption of Regency/City workers in South Kalimantan Province?

\section{Material and methods}

\subsection{Understanding and Definition of Investment}

In general, the investment includes the addition of goods and services in the community such as the addition of new machines, the construction of new roads, and the opening of new land. The economic theory defines investment as expenditures to buy capital goods and production equipment to replace and especially increasing capital goods in the economy that will be used to produce goods and services in the future.

This understanding of investment reinforces what has been conveyed by Alexiou (2009) that investment is a demand for goods and services to create or increase production capacity or income in the future. Investment is a major component in driving the economic development of a country or region. An increase in investment will encourage the volume of trade and production which in turn will expand productive employment opportunities and will mean an increase in per capita income while at the same time increasing the welfare of the community. standard of living of the people, this investment has 3 (three) roles: 
- It is an aggregate expenditure, where an increase in investment will increase aggregate demand and national income

- The increase in capital goods as a result of the investment will increase production capacity in the future and this development stimulates the increase in national production and employment opportunities

- Investment is always followed by technological developments so that it will provide an increase in productivity and income per capita of the community.

Government investment is the long-term placement of funds and goods by the central and local governments for development, securities, direct investment to obtain economic benefits, social benefits, and others. Government investment in spending is in the form of development expenditure. Development expenditure in the form of capital expenditure contributes to providing services to the community and can absorb Employment to encourage increased economic growth which can reduce poverty levels because people's welfare increases (Desai et al, 2005). Private investment is the amount of realized investment value originating from Domestic Investment (PMDN) and Foreign Investment, which is the investment of private or non-government stakeholders.

\subsection{Economic Growth and Economic Development}

Economic growth and development is a process that is demonstrated by government and private policies in managing existing resources and forming a partnership between the government and the private sector to create new jobs and stimulate the development of economic activity (Dollar \& Kraay, 2002). The main problem in economic growth and economic development lies in the emphasis on economic growth and economic development policies based on the uniqueness of each region by using the potential of human resources, institutions, and physical resources locally. This development orientation leads to regional initiatives in the process of creating new job opportunities and stimulating increased economic activity.

Dollar \& Kraay (2002) view that the factor of the amount of capital stock and its development over time will contribute positively to economic growth and people's welfare. Every effort for economic growth and development has the main objective of increasing the number and types of job opportunities to improve the welfare of the community. In this effort, the government and the private sector must jointly take opportunities in the process of economic growth and development in utilizing the necessary economic resources. The theoretical approach to economic growth and development is formulated in development planning which forms the basis for the framework of thinking and action plans in the context of economic growth and economic development.

According to Desai et al (2005), economic growth is an increase in Gross Domestic Product or changes in the level of the economy that apply from year to year. In actual economic activity, economic growth means the development of the financial economy that occurs in a country, such as an increase in the number of production and industrial goods, infrastructure development, an increase in the production of existing economic activities, and various other developments.

\subsection{Employment and Its Absorption}

According to Holzner (2010), the workforce is all people who are willing to be able to work, meaning that all people who do work activities for themselves or others without receiving wages or those who can work. The workforce includes someone who takes care of the household, school, who is looking for work or is working with the age of 14-60 years.

The workforce is the population who are of working age. According to Law no. 13 of 2003 Chapter, Article 1 paragraph 2 states that the workforce is everyone who can do work to produce goods and or services both to meet their own needs and for the community. Broadly speaking, the population of a country is divided into two groups, namely workers and non-workers. The population is classified as a workforce if the population has entered working age. The age limit in force in Indonesia is 15 years - 64 years. According to this understanding, everyone who can work is called a workforce. There are many opinions regarding the age of these workers, some say they are above 17 years old, some say they are over 20 years old.

According to Holzner (2010), Population growth and Employment force growth are traditionally regarded as the positive factors that spur economic growth. A larger number of workers means an increase in the level of production, while a larger population growth means a larger size of the domestic market. However, it is still questionable whether it is true that the rapid rate of population growth will have a positive or negative impact on its economic development. 


\subsection{Research Methods}

Theoretical studies on the thought process framework are used as a theoretical basis for thinking about government investment and private investment and their relation to economic growth, employment, and poverty levels, then followed by empirical studies related to this research. From the study of theories and empirical studies, variables with all their relationships and quality influences can be obtained so that a problem formulation can be formulated which is then compiled into a theoretical analysis (Bastari \& Suharyo, 2020). Theoretical analysis and findings are meaningful statements or postulates whose truth still requires in-depth testing because they are based on analysis of literature studies and observations and reconstructions of previous theoretical theories through in-depth discussions with experts (Bandono et al, 2020).

The following is Figure 1. The Constellation of the Research Model which explains the framework of this research:

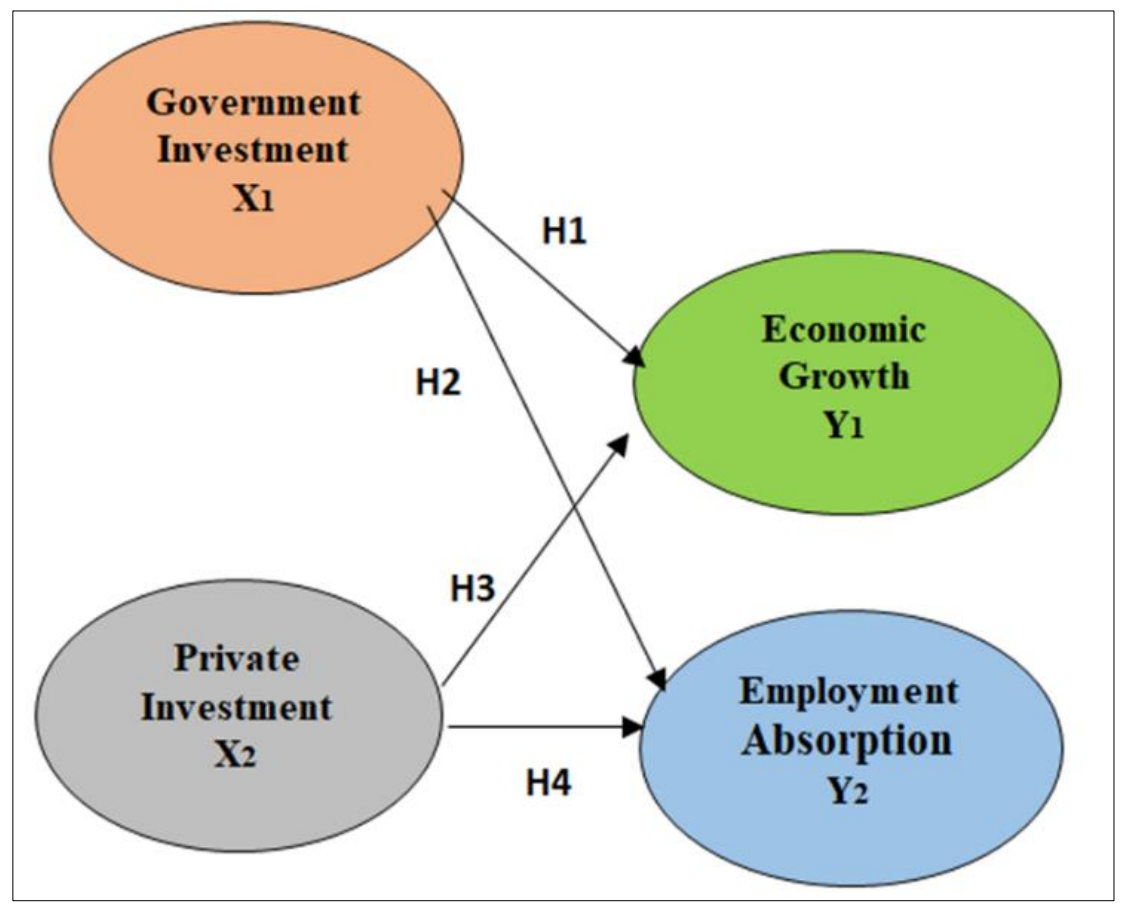

Figure 1 Research Model Constellation

H1: Analysis of theoretical and relationship of $\mathrm{X}_{1}$ on $\mathrm{Y}_{1}$

$\mathrm{H}$ : Analysis of theoretical and relationship of $\mathrm{X}_{1}$ on $\mathrm{Y}_{2}$

H3: Analysis of theoretical and relationship of $\mathrm{X}_{2}$ on $\mathrm{Y}_{1}$

$\mathrm{H} 4$ : Analysis of theoretical and relationship of $\mathrm{X}_{2}$ on $\mathrm{Y}_{2}$

The submission of influence analysis in this study uses Path Analysis and theoretical analysis based on in-depth analysis of various literature studies and researcher observations which are expected to prove that government investment and private investment affect employment and economic growth which in turn can affect poverty levels. The results of the study are expected to obtain important theoretical findings that can contribute to the formulation of government policies.

\section{Results and discussion}

\subsection{The Relationship of Government Investment to Economic Growth}

The results of testing the hypothesis of the effect of government investment on economic growth, using Partial Least Square (PLS) analysis with the help of Smart PLS software, shows an influence coefficient of 0.269 (positive) with a Tstat value greater than 1.96 (significant), which means government investment provide a positive and significant impact on increasing regional economic growth. The positive coefficient also means that the effect of government investment is unidirectional, that is, if government investment increases, it has the potential to significantly increase economic growth. 
The role of government investment in regional development is very important in stimulating and encouraging economic growth, especially in terms of building infrastructure, procurement of public facilities and infrastructure. According to Lin \& Yeh (2009), one of the main component factors of economic growth is capital accumulation which includes all forms of investment invested in land, physical equipment, capital, and human resources. The economic growth of a country is an increase in the country's ability to provide economic goods for its population, increase in capabilities, and advances in technology, institutions, and ideological adjustments.

The government investment that is analyzed for its influence on economic growth is capital expenditure which is a component of direct expenditure in total government expenditure which is allocated for use to finance public sector development. Regional government development activities can increase demand for goods and services that encourage production and increase economic activities that encourage an increase in the formation of the absolute value of Gross Regional Domestic Product (GRDP) and the relative value of changes in GRDP in the form of economic growth.

\subsubsection{Theoretical Analysis of Government Investment to Economic Growth}

To increase national output, the business community does not want to jeopardize investment and consumers do not increase consumption because of uncertain income, the solution that can be done is that the government must spend. The government as an independent agent can stimulate the economy through public works and printing. Expansive government policies can increase effective demand if used without increasing consumption or investment (Holzner, 2010).

The government's fiscal policy improves the people's economy, according to Jhingan, to increase the rate of investment, the government can implement a public sector investment policy that has an impact on increasing the volume of private investment. According to Martinez-Vazquez \& Boex (2001), the role of the government is to maintain defense and security, carry out judicial duties and provide public goods that cannot be provided by the private sector.

Fiscal policy changes government spending and taxes more effective than monetary policy, public work in the form of positive government spending with a multiplier effect. The slightest increase in investment will result in full employment. On the fiscal side, policies are pursued to maintain sustainable fiscal resilience and provide a fiscal stimulus for economic growth. Martinez-Vazquez \& Rider (2006). states that a temporary increase in government spending will lead to a permanent increase in the revenue sector.

Meier \& Stiglitz's (2001) research concludes that development spending has a positive and significant impact on the GRDP of districts/cities in East Java Province. Greater government spending will encourage economic growth. The effect of government expenditure on capital expenditure allocation on economic growth is significant. The results of this study confirm the results of previous studies regarding the effect of government investment in the form of capital expenditures having a significant effect on economic growth, thus supporting the theory of public investment and the theory of economic growth.

Another theoretical finding that supports Minea's (2008) opinion is that the factor of the amount of capital stock and its development from time to time will contribute positively to economic growth and people's welfare. This is because capital expenditure as a government investment can play a significant role in increasing economic growth in districts/cities in South Kalimantan Province.

\subsection{The Relationship of Government Investment to Employment Absorption}

The results of testing the hypothesis of the effect of government investment on employment, using Partial Least Square (PLS) analysis with the help of Smart PLS software show the effect coefficient is only 0.186 (positive) with a T-stat value less than 1.96 (not significant), which This means that government investment does not have a big impact on increasing employment.

The positive coefficient means that the effect of government investment is in line with Employment absorption but the value is small (not significant). The higher the government investment, the more Employment can be absorbed, on the other hand, if there is a decrease in investment, it will reduce the absorption of Employment. Government investment has a direct effect on employment because investment requires Employment, but because of government investment, employment is not as large as a private investment (Holzner, 2010). 


\subsubsection{Theoretical Analysis of Government Investment to Employment Absorption}

The government plays a role in creating job opportunities that are very dependent on the allocation of government spending in the economy, namely capital expenditure. Job opportunities created through government investment can be proven based on the positive coefficient value. Government investment that occurs in government spending in capital expenditures is difficult for the private sector to do. The government's investment in various districts/cities is mostly capital expenditure in infrastructure development that requires capital-intensive, not Employment-intensive. Infrastructure that is built such as roads, bridges, and irrigation requires large government expenditures but cannot absorb a large number of workers. There is also a lot of capital expenditure for the provision of educational facilities, health facilities, transportation facilities, electricity, and water installations so that they cannot absorb more workers (Minea, 2008).

\subsection{The Relationship of Private Investment to Economic Growth}

The results of testing the hypothesis of the effect of private investment on economic growth, using Partial Least Square (PLS) analysis with the help of SmartPLS software, show the effect coefficient is only 0.141 (positive) with a T-stat value less than 1.96 (not significant), which means private investment does not have a large impact on increasing regional economic growth.

The results of this study are consistent with Kuznets's statement in Pressman (2000) that a fairly large private investment in the mining sector comes from PMA so that foreign investors enjoy more investment returns. The contribution of private investment returns in the mining sector to local governments is still very small compared to the central government because local governments only get profit sharing and royalties whose value is very small so that the results cannot be used optimally and freely for regional development.

Minea's (2008) opinion about the three main factors of economic growth in each country, namely capital accumulation, population growth, and technological progress. Economic growth depends on the availability of production factors and the level of technological progress. According to Poulson \& Kaplan (2008) and Minea (2008) that in economic growth the role of investment is to increase production capacity which in turn will increase the effective demand of society and national income. The role of capital accumulation and technological progress tends to increase Employment productivity, the law of diminishing returns, and slow down the decline in the standard of living.

The role of investment in the economy is to encourage economic growth to increase production capacity, improve product quality and create jobs. Through investment, economic activity will develop and the welfare of the community will increase. A study on the important role of investment in economic development has been carried out by Poulson \& Kaplan (2008) regarding the stages of economic growth. The development of a country's economic development through the stages of traditional society, pre-requisites for take-off, take-off, towards maturity, a period of high consumption. A country is said to take off when it meets the following characteristics:

- Applicable increase in productive investment from $5 \%$ or less to $10 \%$ of the net national product.

- Enactment of the development of one or several industries with a high growth rate.

- Creating a basic political, social and institutional framework that will create a reality for the expansion of the modern sector and the growth of the external economic sector so that the process of economic growth will continue.

Then according to Nugroho \& Afifah (2021), the theory of economic growth also requires investment activities to achieve economic growth and changes in economic structure. Likewise, Nelson's theory requires a high level of investment so that people can escape the low-level equilibrium trap. The process of capital growth according to Minea (2008) depends on the ability to save and the willingness to save, the greater the surplus the higher the ability to save.

\subsubsection{Theoretical Analysis of Private Investment to Economic Growth}

The findings of this study are different from the existing theory, namely that private investment does not have a significant effect on economic growth. The study findings are reinforced by Minea (2008), that more savings and investment are no longer a necessary condition for increasing economic growth. Holzner (2010) confirmed that economic growth is not only influenced by aggregate economic variables, namely changes in output and productivity increases but is also influenced by structural transformation variables. Albouy's previous research (2010) concluded that private investment has no significant effect on economic growth, thus this study supports the results of the previous research. 
Albouy's analysis (2010) states that the purpose of putting forward a theory about the development process that is specifically intended for countries experiencing the problem of excess Employment. His dissatisfaction with neoclassical and Keynesian theory was not in favor of developing countries. The neoclassical view is that the supply of Employment in society is not excessive, while Keynes assumes that there is not only an excessive supply of Employment but also the available land and production capacity is unlimited. This situation is contrary to the situation in developing countries. Lewis considers that many developing countries have excessive Employment but instead face the problem of lack of capital.

The development process in an economy that is experiencing an excess of manpower is seen from the aspect of the pattern of the economic growth process, the factor of a higher level of investment, and the factors that cause the development process to not apply. The economy is divided into capitalist and subsistence sectors, when capitalist sector activities generate profits, funds are reinvested which creates job opportunities. This theoretical finding is reinforced by that in the end investment will increase production and economic development. As a result of this activity more economic activity is carried out in the capitalist sector more opportunities are created in that sector (Holzner, 2010).

Furthermore, according to Holzner (2010), analyzing an investment in the industrial sector and overall capital accumulation in the modern sector will lead to an expansion of output in the modern sector. The higher the per capita income of a country, the smaller the role of the agricultural sector in providing employment, on the contrary, the role of the industrial sector is increasingly important. The shift of Employment from the agricultural sector to the modern sector (industry) will further increase output growth and increase employment. Economic growth depends on the availability of factors of production of the population, Employment, accumulation of capital, and the level of technological progress. In the Lewis assumption, the rate of Employment transfer and job creation in the modern sector must be proportional to the rate of capital accumulation in the modern sector.

The findings of this study are different from the existing theory, namely that economic growth has no significant effect on employment. This theoretical finding is consistent with the opinion of Albouy (2010) that reinvestment is in the form of more sophisticated and more Employment-efficient capital goods. To increase output and future income, reinvestment is carried out by developing countries to develop industrial sectors that are not Employment intensive. Capital flight abroad can occur in the form of additional deposits at new banks. The scarcity of Employment occurs in rural areas while unemployment is also increasing in urban areas due to an unbalanced shift in the economic structure as a structural transformation of the economy from a traditional agricultural economy to a modern industrial economy in urban life patterns.

There is an allegation that there is an excess of Employment in rural areas, while in urban areas there is a fall in employment and the surplus of Employment supply is used up is unacceptable, so this opinion supports this theoretical finding where economic growth does not significantly affect employment. Changes in Employment in the first stage of subtle unemployment in the agricultural sector shifted to the industrial sector with the same wages, the second stage workers in the low productivity agricultural sector were shifted to the industrial sector with the same wages and the third excess Employment in the agricultural sector had been absorbed entirely in the industrial sector and the agricultural sector. modern commercial agriculture. Arthur Lewis's growth model explains the process of Employment transfer as well as output growth and increased employment in the urban sector (modern) which is influenced by the level of investment and capital accumulation in the industrial sector. So the findings of the study on the effect of economic growth on energy absorption are not significant, which means that they reject the theory that has been described but support the theory that on the contrary also rejects the effect of economic growth on absorbing Employment.

\subsection{The Relationship of Private Investment to Employment Absorption}

The results of testing the hypothesis of the effect of private investment on employment, using Partial Least Square (PLS) analysis with the help of Smart PLS software show an influence coefficient of 0.144 (positive) with a T-stat value greater than 1.96 (significant), which means the more High private investment will have a big impact on increasing employment. Private investment invested in districts/cities in South Kalimantan Province is an investment in the rubber plantation sub-sector which has absorbed a lot of Employment for a long time, then the oil palm plantation sub-sector has absorbed a lot of Employment through land clearing, seeding, processing, planting, maintenance, and harvesting. , as well as investment in the animal feed industry, which absorbs a lot of Employment. The high absorption of Employment is supported by adequate human resources and able to access the jobs offered.

The high planned and realized investment in the plantation sub-sector plays an important role in absorbing the workforce, as well as the coal mining sector which is also quite large in absorbing the workforce. However, another 
problem is the high in-migration from outside the region to work in the mining and plantation sectors, making them the main competitors for local workers. When the regional economy declines, the magnitude of in-migration to find work will have consequences for unemployment which in turn becomes a burden on the region.

Capital accumulation occurs when part of the income is saved and reinvested to increase output and income. The NeoClassical model of capital accumulation and economic growth can accelerate output growth but slow job creation. If the main goal of development is to maximize the growth rate of GNP then it can be justified. However, if what is more important is job creation, then other policies need to be made, such as encouraging Employment-intensive industries in the agricultural sector and small industries (Holzner, 2010).

\subsubsection{Theoretical Analysis of Private Investment to Employment Absorption}

An increase in investment can lead to an increase in income, with an increase in income causing a greater demand for goods and services which in turn leads to an increase in income and employment. The role of capital accumulation and technological progress will tend to increase work productivity and slow down the occurrence of The Law of Diminishing Return. Larger investment is needed which can ensure that in the long term the rate of economic growth is always greater than the rate of population growth in the application of the theory of balanced development. Balanced big push theory assumes that industrializing in less developed areas is a way to increase income more evenly and to increase incomes in such areas more quickly than in richer areas (Albouy, 2010). The findings of the study of the effect of private investment on employment are significant, which means that accepting the theory of capital accumulation and private capital formation can affect employment.

\section{Conclusion}

Based on the analysis of the results of the study and discussion of the effect of government investment and private investment on economic growth, employment, and poverty levels in districts/cities in South Kalimantan Province, the following conclusions are drawn:

- $\quad$ Government investment has a positive and significant effect on economic growth in districts/cities in South Kalimantan Province, a positive coefficient means that if government investment increases, economic growth will also increase significantly.

- Government investment has no significant effect on employment in regencies/cities in South Kalimantan Province, meaning that the higher government investment does not have a large impact on increasing Employment absorption.

- $\quad$ Private investment has no significant effect on economic growth in districts/cities in South Kalimantan Province, meaning that the higher private investment does not have a large impact on increasing economic growth.

- $\quad$ Private investment has a positive and significant impact on employment in districts/cities in South Kalimantan Province, a positive coefficient means that if private investment increases, employment will also increase significantly.

\section{Recommendation}

- $\quad$ Based on the results of the analysis, it shows that government spending tends to have a direct effect on economic growth, while private investment tends to affect employment. This indicates that government spending is a very strong variable affecting economic growth so that it can reduce the poverty rate in South Kalimantan Province. Thus, this government investment should be prioritized to increase economic growth to reduce poverty levels in districts/cities in South Kalimantan Province.

- $\quad$ Strategies to reduce poverty levels in districts/cities in South Kalimantan Province must be carried out by increasing Employment absorption through increasing the realization of private investment, both foreign and domestic, to increase employment so that it contributes to poverty reduction. An increase in private investment will be able to increase employment, which in turn will reduce poverty.

\section{Compliance with ethical standards}

\section{Acknowledgments}

The authors greatly acknowledge the support from the Sekolah Tinggi Ilmu Ekonomi Pancasetia (STIEPAN) Banjarmasin Indonesia for providing the necessary resources to carry out this research work. The authors are also 
grateful to the anonymous reviewers and journal editorial board for their many insightful comments, which have significantly improved this article.

\section{Disclosure of conflict of interest}

The authors declared no potential conflicts of interest concerning the research, authorship, and/or publication of this article.

\section{References}

[1] Aan Zulyanto S, Muljarijadi B, Purnagunawan RM. The Effect of Government Fragmentation and Fiscal Decentralization on Economic Growth in Indonesia. DLSU Business \& Economics Review. 2019; 28(3): 91-103.

[2] Akai N, Nishimura Y, Sakata M. Complementarity, fiscal decentralization, and economic growth. Economics of Governance. 2007; 8(4): 339-362.

[3] Albouy D. Evaluating the efficiency and equity of federal fiscal equalization (No. w16144). National Bureau of Economic Research. 2010.

[4] Alexiou C. Government spending and economic growth: Econometric evidence from South-Eastern Europe (SEE). Journal of Economic and social research. 2009; 11(1): 1.

[5] Astika IMJ, Bastari A, Suharyo OS. The Policy Of Environmental And Sustainable Development In Indonesia. International Journal of Progressive Sciences and Technologies. 2021; 27(1): 267-276.

[6] Bandono A, Bastari A, Suharyo, OS. Effectiveness Naval ColEmploymentation Flexible Learning (NCFL) Model in Increasing Learning Outcomes The Indonesian Naval Technology College. International Journal of Progressive Sciences and Technologies. 2020; 23(2): 434-442.

[7] Bastari A, Suharyo OS. Analysis of The Implementation of Occupational Safety Program Efforts to Improve Work Productivity With Fault Tree Analysis Approach. International Journal of Progressive Sciences and Technologies. $2020 ; 23(2): 728-733$.

[8] Dollar D, Kraay A. Growth is Good for the Poor. Journal of economic growth. 2002; 7(3): 195-225.

[9] Desai RM, Freinkman L, Goldberg I. Fiscal federalism in rentier regions: Evidence from Russia. Journal of Comparative Economics. 2005; 33(4): 814-834.

[10] Holzner M. Inequality, growth, and public spending in Central, East, and Southeast Europe (No. 71). WIIW Working Paper. 2010.

[11] Lin YC, Yeh CC. Joint determinations of inequality and growth. Economics Letters. 2009; 103(3): 163-166.

[12] Martinez-Vazquez J, Rider M. Fiscal decentralization and economic growth: a comparative study of China and India. Indian Journal of Economics and Business. 2006; 29-46.

[13] Martinez-Vazquez J, Boex J. The design of equalization grants: theory and applications. Andrew Young School of Policy Studies: Georgia State University. 2001.

[14] Meier GM, Stiglitz JE. (Eds.). Frontiers of development economics: the future in perspective. World Bank Publications. 2001.

[15] Minea A. The role of public spending in the growth theory evolution. Romanian Journal of Economic Forecasting. 2008; 2: 99-120.

[16] Nugroho SH, Afifah S. The Relationship Of Organizational Justice And Job Embeddedness On Turnover Intention With Mediation Of Organizational Commitment. International Journal of Progressive Sciences and Technologies. 2021; 29(1): 335-346.

[17] Poulson BW, Kaplan JG. State income taxes and economic growth. Cato J. 2008; 28: 53.

[18] Pressman S, Summerfield G. The economic contributions of Amartya Sen. Review of political Economy. 2000; 12(1): 89-113. 